\title{
LGALS3 wt Allele
}

National Cancer Institute

\section{Source}

National Cancer Institute. LGALS3 wt Allele. NCI Thesaurus. Code C104858.

Human LGALS3 wild-type allele is located in the vicinity of $14 q 22.3$ and is approximately

$21 \mathrm{~kb}$ in length. This allele, which encodes galectin-3 protein, is involved in both carbohydrate recognition and immunity. 